Tanzīh and Tashbīh in Classical Islamic Theological Thought". In

Oxford Bibliographies Oxford Bibliography in Islamic Studies, https:// www.oxfordbibliographies.com/view/document/ Your Best Research Starts Here obo-9780195390155/obo-9780195390155-0251.xml (accessed 16 Apr. 2021).

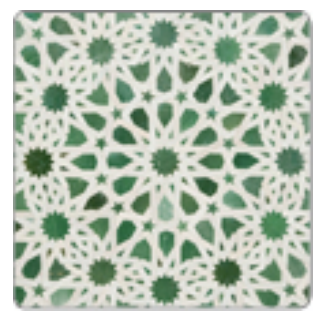

\title{
Tanzīh and Tashbīh in Classical Islamic Theological Thought
}

\author{
Mustafa Shah
}

LAST MODIFIED: 24 MAY 2018

DOI: 10.1093/OBO/9780195390155-0251

\section{Introduction}

Debates and arguments surrounding the questions of tanzīh (transcendence) and tashbīh (anthropomorphism) were a dominant feature of the discourses of early and classical theological thought. Within these discourses, the former term, tanzih, was intricately entwined with the conception of God's absolute transcendence and pre-eminence; while, the term tashbih retained a rather pejorative connotation as it was associated with the conceptualization and description of God and his divine attributes using human characteristics and qualities as analogues; indeed, the verb from which the verbal noun tashbih is derived signifies the act of likening or equating. Theological movements and schools of thought were defined by their respective standpoints on the notions of tanzīh and tashbīh, although scholars who were accused of adopting anthropomorphic positions repudiated such allegations, claiming that they were essentially advocating tanzīh. While the Qur'an includes imposing statements which describe God as being "without peer or equal" (Q. 42:11; and Q. 112:4), and refer to him as "omniscient, omnipotent and sublime" (Q. 2:255; Q. 6:101-6; Q. 42:19), it also makes ample use of metaphors, forms of comparison, and imagery to exemplify and describe the personal and close nature of his relationship with mankind. The Qur'an even describes God as being "closer to man than his jugular vein" (Q. $50: 16)$ in ways which underscore his divine immanence. The conceptual significance of such Qur'anic dicta was soon pored over within rational theological discourses in which arguments about transcendence and anthropomorphism loomed large. The associated terminology which features in the discussions includes ta 'till (negation), which was a label used to deride those who "stripped or divested God of his attributes"; tajsim, which in contrast was a term used to besmirch those who associated God with physical presence and form; also connected to this was the term hashwiyya which has negative connotations in the history of classical Islamic thought as it was used to impute and vilify those religious movements who were accused of anthropomorphism. Separately, ta'wil, whose original meaning denotes interpretation or explanation, was used in a theological context to indicate the "obviation" of the literal meanings of language when conceptualizing God and his attributes. Within the tradition, there were also scholars who refrained from proffering opinions on the meaning of such sensitive Qur' anic passages and dicta discussing the divine attributes, and they adopted a strategy referred to as tafwīo or "delegation." Mapping the precise historical trajectory of the gestation of these concepts together with their sundry terminology and the reasons why they became such contentious topics in Islamic theology remains a tentative exercise: the earliest theological sources tend to be fragmentary, while later literary sources are separated in time from the periods to which they refer; and in such sources adversaries sometimes misrepresent the perspectives of opponents. Still, the significance of the discussions on tanzīh and tashbih ensured that they remained at the forefront of developing classical theological discourses, even resurfacing in the context of debates about Islamic reform and modernity. Significantly, safeguarding a conception of God whose transcendence is unique lay at the heart of Islamic philosophical discussions.

\section{Encyclopedia and Handbook Entries}

The subjects of tanzīh and tashbīh along with selected terms connected with their synthesis have been treated in a number of encyclopedia entries, either together or as individual themes or topics. In the context of theological approaches to the conceptualization of the divine attributes, Gilliot 2007 situates these discussions within the vector of broader debates about tanzin and tashbih. Despite being written in the 1920s, Strothmann's entry (Strothmann 1913-1936) on anthropomorphism sketches the broader context to the discussions, although it is based on a confined range of sources. Van Ess 2011 is typically in-depth and informative, offering one of the most detailed treatments of these two concepts. Providing a review of the historical context of the arguments about tashbih, Holtzman 2011 identifies the position taken by different religious movements and scholars on the issues. Schöck 2016 introduces the theories of Jahm ibn Șafwān (d. 128/745) and Ḍirār ibn 'Amr (d. 200/815); traditional sources intimate 
that the former figure was influential in arguing that the transcendence of God necessitated that he should not be defined using terms or descriptors which are applied to humans, while Dirār's views on atomism were deemed revolutionary. Physically seeing God and the stance taken by different theological schools on the notion is examined in Gimaret 2012. Bennett 2016 discusses the philosophical system of the Mu tazila, analyzing the movement's doctrines on the divine attributes and nature of God. And useful historical context to the discussions on tanzīh and tashbīh is provided in Van Ess 1987. The views of the Karrāmiyya, a medieval Islamic sect renowned for its espousal of anthropomorphic depictions of the divine, are the subject of a reassessment in Zysow 2016. Finally, Williams 2009 reviews the origins of notions of tashbīh within the pre-lslamic and Semitic traditions with the express aim of understanding early Arab receptivity to such ideas.

Bennett, David. "The Mu tazilite Movement (II): The Early Mu tazilites." In The Oxford Handbook of Islamic Theology. Edited by Sabine Schmidtke, 142-158. New York: Oxford University Press, 2016.

The chapter presents an account of their teachings on tawhid.

Ess, J. van. "Tashbīh wa-Tanzīh.” In Encyclopaedia of Islam. 2d ed. Edited by P. Bearman, Th. Bianquis, C. E. Bosworth, E. van Donzel, W. P. Heinrichs. Leiden, The Netherlands: E. J. Brill, 2001.

A wide-ranging survey is offered in this entry which is based on a wealth of original research by the author.

Gilliot, Claude. “Attributes of God.” In Encyclopaedia of Islam THREE. 3d ed. Edited by Kate Fleet, Gudrun Krämer, Denis Matringe, John Nawas, and Everett Rowson, 176-182. Leiden, The Netherlands: Brill, 2007.

Discussions on this subject were intrinsic to the wider debates about transcendence and anthropomorphism within theological movements and these are given some context in this survey.

Gimaret, Daniel. "Ru'yat Allāh.” In The Encyclopaedia of Islam. 2d ed. Vol. 8. Edited by P. Bearman, Th. Bianquis, C. E. Bosworth, et al., 649ff. 2d ed. Leiden, The Netherlands: Brill, 2012.

This probes the various theological implications of the notion of the beatific vision, reviewing how presuppositions informed the debates.

Holtzman, Livnat. “Anthropomorphism.” In Encyclopaedia of Islam THREE. 3d ed. Edited by Kate Fleet, Gudrun Krämer, Denis Matringe, John Nawas, and Everett Rowson, 46-55. Leiden, The Netherlands: Brill, 2011.

The distinctive feature of this study is its summary of the significance of discussions on anthropomorphism in early and classical materials.

Schöck, Cornelia. “Jahm b. Șafwān (d. 128/745-6) and the 'Jahmiyya' and Ḍirār b. 'Amr (d. 200/815).” In The Oxford Handbook of Islamic Theology. Edited by Sabine Schmidtke, 55-80. New York: Oxford University Press, 2016.

In the history of the origins of discussions about tanzih, tashbih , the divine attributes, and the cosmology of creation, the contribution of these two figures is seminal.

Strothmann, R. "Tashbīh.” In Encyclopaedia of Islam. 4 vols. Edited by M. Th. Houtsma, T. W. Arnold, R. Basset, and R. Hartman. Leiden, The Netherlands, and London: Brill, 1913-1936.

An outline of the various discussions about tashbih is attempted in this piece.

Van Ess, Josef. "Mu tazila." In Encyclopedia of Religion. Edited by Mircea Elidade, 220-229. New York: Macmillan Press, 1027 
Issues of influence and originality are covered in this brief overview of Mu tazili thought and its teachings on tawhid are explained.

Williams, Wesley. "A Body Unlike Bodies: Transcendent Anthropomorphism in Ancient Semitic Tradition and Early Islam." Journal of the American Oriental Society 129.1 (January-March 2009): 19-44.

This article does try to locate the discussions within the context of much broader debates about Islamic origins.

Zysow, Aron. "Karrāmiyya." In The Oxford Handbook of Islamic Theology. Edited by Sabine Schmidtke, 252-262. New York: Oxford University Press, 2016.

The Karrāmiyya are traditionally portrayed in the classical sources as arch-anthropomorphists and in this chapter an evaluation of their historical position on tashbih is presented.

\section{Surveys of Theological Thought: Tanzīh and tashbīh in Context}

Doctrinal discussions germane to the notions of tanzīh and tashbīh form one of many elements of rational theological discourses which feature in a number of general surveys, histories, and reference works on Islamic theology. Having an overall view of the range of the discussions will help identify the wider historical context of the various arguments and stances. The work of Josef van Ess 1991-1997 has been hugely influential and the Theologie und Gesellschaft is considered to be the authoritative reference work for the study of theological movements and thought in early Islam. References to debates about tanzih and tashbih frequently occur in the study of movements and figures and van Ess's appreciation of the attendant arguments is unrivaled in academic circles. Interestingly, Volume 1 of the work has been translated by John O'Kane under the title: Theology and Society in the Second and Third Century of the Hijra. Vol. 1. A History of Religious Thought in Early Islam (Leiden, The Netherlands: E.J. Brill, 2016). In van Ess 1988 an assessment is provided of the theological factors that shaped exegetical discussions in the early tradition. Holtzman's 2018 survey is an indispensable resource for the study of traditionalist perspectives on the subject of anthropomorphism. Schmidtke 2016 brings together a range of chapters in which the divine attributes, the nature of God, anthropomorphism, and transcendence are discussed across a range of contexts and historical frameworks of enquiry. The doctrinal positions taken by individual theological schools and movements are therefore treated at length throughout the book. The collection of articles and entries in Nasr and Leaman 1996 is aimed at furnishing a history of Islamic philosophy, yet it includes chapters which cover discussions on tanzīh and tashbih. The historical survey in Watt 1998 can be used to gauge the gestation and evolution of arguments about transcendence and anthropomorphism. A detailed study of anthropomorphism with reference to specific Prophetic traditions is defined in the monograph Gimaret 1997. It presents not only traditionist defenses of such materials, but also the reaction to them by rationalist theologians who sought to obviate the anthropomorphic imagery contained in them. The classical Islamic treatise on sects and movements (al-milal wa'l-nihal) was composed by the 10th-century scholar al-Shahrastāni and a translation of the initial parts of the texts was made by Kazi and Flynn; the book provides readers with a sense of polemical discussions in the original sources. Creedal summaries and statements defined by schools of theological thought are translated in the text in Wensinck 1932. Netton 1994 casts his net much wider, assessing discussions on the subject of gnosis, emanation, and theosophy within Sufism, Isma'ili, and philosophical thought. On a more general note, Winter has edited a volume which brings together scholarship on classical Islamic theology; it includes the contribution by El-Bizri 2008 in which he locates notions of tanzih and tashbih within the framework of the conceptual discussions surrounding the divine attributes. Gardet and Anawati 1981 devotes lengthy sections to Ashari theology. Shah 2014 highlights instances in which specified arguments about the divine attributes, transcendence, and anthropomorphism feature in early and classical theological discourses; and, debates about tanzīh and tashbīh were referenced within discourses on Islamic reform and modernity. This is evident in the thought of the Egyptian reformer Muhammad 'Abdu and indeed the Indian thinker Mohammed Iqbal. Abdu was the author of an epistle titled "Kitab al-Tawhīd," (The Theology of Unity); which was translated by Musa'ad and Cragg ('Abdu 1966); Iqbal published The Reconstruction of Religious Thought in Islam in which he grappled with reconciling traditional notions about divine immanence with philosophical perspectives. His legacy is assessed in Mir 2017.

\section{'Abdu, Muhammad. The Theology of Unity. Translated by Ishaq Musa'ad and Kenneth Cragg. London: George Allen \& Unwin, 1966.}

A chapter in the work is devoted to the divine attributes and also included in the text are attempts to explain key theological beliefs 
with the aim of responding to the challenges of modernity.

El-Bizri, Nader. "God: Essence and Attributes." In The Cambridge Companion to Classical Islamic Theology. Edited by Tim Winter, 121-140. Cambridge, UK: Cambridge University Press, 2008.

Key concepts such as ta 'țīl (negation) and ithbāt (affirmation) are explained against the background of wider theoretical developments.

Gardet, L., and G. Anawati. Introduction à la Théologie musulmane. 2d ed. Paris: Vrin, 1981.

This remains an important reference work and source for the history of kalām in its classical context with particular reference to the thought of the Ash'arīs. Originally published in 1948.

Gimaret, Daniel. Dieu à l'image de l'homme: les anthropomorphismes de la sunna et leur interprétion par les théologiens. Paris: Cerf, 1997.

Focusing on the principal theoretical complexities of Sunni theologians' attempts to grapple with conceptions of anthropomorphism, Gimaret collates various hadiths from canonical and non-canonical sources relative to tashbih. The traditions are classified according to subject-matter and analyzed in terms of variants and transmission.

Holtzman, Livnat. Anthropomorphism in Islam: The Challenge of Traditionalism (700-1350). Edinburgh: Edinburgh University Press, 2018.

This covers centuries of discourses on the subject of anthropomorphism, providing a veritable wealth of insights.

Kazi, A. K., and J. G. Flynn, trans. Muslim Sects and Divisions: The Section on Muslim Sects and Divisions. By Muhammad b. 'Abd al-Karīm Shahrastānī. London and Boston: Kegan Paul International, 1984.

This partial translation of this seminal heresiographical text covers the original doctrinal positions taken by classical schools of theology on issues relating to transcendence and anthropomorphism.

Mir, Mustansir. "Muhammad Iqbal (d. 1938): The Reconstruction of Religious Thought in Islam." In The Oxford Handbook of Islamic Philosophy. Edited by Khaled El-Rouayheb and Sabine Schmidtke. New York: Oxford University Press, 2017. This study shows how lqbal attempted to discuss the issues of social and political reform at the philosophical level.

Nasr, Hossein, and Oliver Leaman, eds. History of Islamic Philosophy. Routledge History of World Philosophies. London and New York: Routledge, 1996.

Selective views of individual theologians and philosophers on subjects related to tashbīh and tanzīh feature in various chapters of the work. It is an excellent reference source.

Netton, lan. Allah Transcendent: Studies in the Structure and Semiotics of Islamic Philosophy, Theology and Cosmology. London: Curzon, 1994.

A wide range of philosophical and theological systems of thought and arguments forms the subject matter of this book; and arguments about the nature of God feature throughout. 
This handbook covers not only the early historical periods, but also extends to medieval and contemporary developments in theological discussions.

Shah, Mustafa. "Kalām: Rational Expressions of Medieval Theological Thought." In Encyclopedia of Mediterranean Humanism. Edited by Houari Touati. Spring, 2014.

Individual theologians whose contribution to debates about the divine attributes are introduced. Available online.

Van Ess, Josef. The Youthful God: Anthropomorphism in Early Islam. Tempe: Arizona State University Department of Religious Studies, 1988.

This brief tract was originally a lecture delivered by van Ess at Arizona State University.

Van Ess, Josef. Theologie und Gesellschaft im 2. 3. jahrhundert Hidschra. 6 vols. Berlin: Walter de Gruyter, $1991-1997$.

A comprehensive survey of movements and key thinkers is achieved in this work and arguments germane to tanzīh and tashbīh feature throughout.

Watt, Montgomery. The Formative Period of Islamic Thought. Oxford: Oneworld, 1998.

This text provides an accessible overview of the theological controversies surrounding tashbïh and tashbih, and the various arguments concerning the divine attributes are reviewed. Originally published in 1973.

Wensinck, Arent Jan. The Muslim Creed: Its Genesis and Historical Development. London: Frank Cass, 1932.

This is considered a very important sourcebook for early Islamic creeds; it includes translated materials.

\section{Syntheses of the Constructs of Tanzīh and Tashbīh}

The epistemology of defining the nature of God's speech played an important role in the unfolding of the mihna (inquisition), when the Abbasid caliph al-Ma'mūn (ruled 813-833 CE) adopted the doctrine that the Qur' an was created as the official state creed in 198/833 CE. Significantly, notions of tanzīh and indeed tashbīh are salient in the constellation of arguments presented by the various protagonists. The historical genesis of the doctrine and its anthropomorphic implications are addressed in Madelung 1974. In an article, Nawas 1994 assesses the principal arguments outlined in several studies of the mihna, weighing up their viability. The reason as to why rational theologians were key players in this controversy and the theological gravity of the issues at stake feature in the study by Hurvitz 2001. Historical perceptions of the events of the mihna and the portrayal of the role of Ibn Hanbal (d. 241/855 CE) during the episode are explored in Cooperson 2000. Turner 2013 has argued that although there is a tendency to present the mihna as a watershed event in the history of theology, the caliph's intervention is not to be viewed as being novel; he concludes that later figures inflated the historical significance of the mihna in order to exaggerate the role of Ibn Hanbal. The strategic use of the term bi la-kayf, which intimated the adoption of a neutral position of amodality (acceptance without qualification) when articulating doctrinal views about the divine attributes, is explained in Abrahamov 1995. In the first of his two separate studies on anthropomorphism in Watt 1951, early trends and themes in the discourses are identified; while, in the author's second study Watt 1959-1960, the theological ramifications of the tradition, which alludes to Adam being created in the image of God, are investigated. Historical trajectories of the debates about the Prophet's witnessing God are pored over in Melchert 2015. Anthropomorphic implications of views concerning the idea of God's laughing, which was conceptually linked to questions about whether the divine essence can serve as a substrate for temporal accidents, are the subject of the chapter in Holtzman 2010. Switching to the subject of interfaith polemics, Thomas 2002 provides an edited translation of a treatise by an "unorthodox" Muslim theologian in which the Christian doctrine of incarnation together with its anthropomorphic connotations is critiqued. 
Abrahamov, Binyamin. "The Bi-lā Kayfa Doctrine and Its Foundations in Islamic Theology.” Arabica 42.3 (1995): $365-379$. Abrahamov circumscribes three different ways in which early and classical theologians interpreted anthropomorphic expressions in the primary textual sources.

Cooperson, Michael. Classical Arabic Biography: The Heirs of the Prophet in the Age of al-Ma'mūn. Cambridge, UK: Cambridge University Press, 2000.

A key chapter on Ahmad ibn Hanbal and his arguments on the uncreated Qur'an is included in the book. And the issue of whether Ibn Hanbal capitulated under interrogation is considered.

Holtzman, Livnat. "Does God Really Laugh? Appropriate and Inappropriate Descriptions of God in Islamic Traditionalist Theology." In Laughter in the Middle Ages and Early Modern Times. Edited by Albrecht Classen, 165-200. Berlin: de Gruyter, 2010.

The broader theological implications of the various positions are explained.

Hurvitz, Nimrod. “Mihna as Self-defense.” Studia Islamica 92 (2001): 93-111.

This study is predicated on rejecting Sunni accounts of the affair and seeking to understand the reaction of the rationalists.

Madelung, Wilferd. "The Origins of the Controversy Concerning the Creation of the Qur'ān." In Orientalia Hispanica: sive studia FM, Pareja octogenaria dicata. Edited by Félix M. Pareja Casañas, 504-525. Leiden, The Netherlands: E. J. Brill, 1974.

Nuances within the arguments and debates which feature in the controversy about the status of the Qur'an are painstakingly fleshed out in this article. Critically, it also addresses the import of the contribution to the discussions by medieval scholarship.

Melchert, Christopher. "The Early Controversy over Whether the Prophet Saw God.” Arabica 62.4 (2015): $459-476$.

This traces some of the key junctures in the development of the discussions as to whether the Prophet physically witnessed God as alluded to in the Qur'an, biographical sources, and selected Prophetic traditions.

Nawas, John. "A Re-examination of Three Current Explanations for Al-Ma'mūn's Introduction of the Mihna." International Journal of Middle East Studies 26.4 (1994): 615-629.

An overview of the different interpretations of the events of the mihna and their wider historical context is presented.

Thomas, David. Early Muslim Polemic against Christianity: Abū 'Īsā al-Warrāq's “Against the Incarnation"'. Cambridge, UK: Cambridge University Press, 2002.

The text confirms the sophistication with which Islamic discussions on tanzīh and tashbīh were brought to bear in polemical interfaith disputes. 
Turner, John P. Inquisition in Early Islam: The Competition for Political and Religious Authority in the Abbasid Empire. London: I. B. Tauris, 2013.

This extensive survey challenges prevailing arguments about the mihna and its overarching historical importance. It also advances the theory that its impact was exaggerated in later historical periods, implicating key Hanbali scholars in accentuating the prominence of Ibn Hanbal during the episode.

\section{Watt, Montgomery. "Some Muslim Discussions of Anthropomorphism." Transactions of the Glasgow University Oriental Society 1947-1949 13 (1951).}

The historical background to the elevation of discussions on tashbih and the role of groups such as the Mu tazila and the so-called jahmiyya is mapped out.

\section{Watt, Montgomery. “Created in His Image." In Transactions of the Glasgow University Oriental Society 18 (1959-1960): 38-49.}

This examines the broader implication of the dictum which was used by certain traditionists who spoke of Adam being created in the image of God. Later rational theologians criticized the interpretation.

\section{Religious Movements and Schools of Thought}

The pre-eminence of Sunni theological discourses as a default position of traditionalism in histories of Islamic theology has been challenged by a number of researchers. Still, the crystallization of a body of doctrines and beliefs, many of which were articulated as a result of the reaction to and the repudiation of conflicting doctrines and ideas, does become a distinctive hallmark of what was eventually defined as Sunni orthodoxy. Nevertheless, the label Sunni became an umbrella term which encompassed groups and movements with diverse views on theological matters and the issues of approaches and methodology. The materials cited below confirm the extent to which definitions of the notions of tanzihh, tashbihh, and the divine attributes varied within Sunni camps. It is interesting to note that tensions within these camps on such subjects remained inexorably acute throughout the course of the history of theological thought.

\section{Traditionists (ahl al-hadith)}

The term traditionists, or ahl al-hadith, has generally been associated with those individuals who pursued a very conservative approach to engaging in or endorsing dialectics and the doctrinal theses yielded within such rational theological frameworks, upholding the so-called "orthodoxy" of the pious ancestors. Ibn Hanbal is, of course, viewed as the archetypal traditionist who eschewed kalām and challenged doctrines which he condemned as being in contravention of the accepted Sunna. His teachings on the subject of tashbih are examined in Williams 2002, although it should be noted that such figures viewed themselves as being vociferous critics of tashbih. Doctrinal statements associated with the theology of Ahmad Ibn Hanbal are examined in Al-Sarhan and Melchert 2014. Remaining with the subject of creeds, Al-Sarhan 2011 thesis also examines issues of attribution and origins. The threads of traditionalism and theological orthodoxy, which include approaches to tanzīh and tashbīh as manifested in the Hanbali legal school, form a key theme which informs the study of Hurvitz 2002. Laoust 1958 surveys the theological perspectives of lbn Bațta (d. 387/997 CE), offering valuable insights into the traditionist approach to conceptualizing the divine attributes. Later doctrinal stances within the Hanbali school are assessed in Hoover 2016. The study of the Hashayiyya in Halkin 1934 gives a fascinating account of the origin of this label and its signification. The legacy of al-Tabarī (d. 310/923 CE) together with his teachings and position on issues relating to tanzīh and tashbīh is explored in the studies of Gilliot 1990 and Shah 2013. Medieval treatments of traditionist doctrine are covered in Daiber 1981 and Swartz 2002, who has furnished a translation of the celebrated critique of anthropomorphism by Ibn al-Jawzī (d. 597/1200 CE). He was a medieval Hanbalite scholar and respected Hadith specialist who defied many of his Hanbali peers by disavowing their doctrinal position on tanzīh, and accusing many of them of anthropomorphism. Remaining within the medieval periods, Ibn Taymiyya (d. 728/1328 CE) and Ibn al-Qayyim (d. 751/1350 CE) are presented as staunch defenders of arch-traditionist orthodoxy on the issue of upholding tanzīh, but their opponents accuse them of abject anthropomorphism and within this context Holtzman 2016 addresses the ramifications of what was at stake in the arguments. 
Al-Sarhan, Saud. "Early Muslim Traditionalism: A Critical Study of the Works and Political Theology of Ahmad Ibn Hanbal." PhD thesis., Exeter University, 2011.

Detailed studies of the creeds are also featured in this unpublished thesis.

Al-Sarhan, Saud, and Christopher Melchert. "The Creeds of Ahmmad ibn Ḥanbal." In Books and Bibliophiles: Studies in Honour of Paul Auchterlonie on the Bio-Bibliography of the Muslim World. Edited by Robert Gleave, 29-44. Oxford: Gibb Memorial Trust, 2014.

This contribution is essentially made up of two parts: in the first part Sarhan introduces and examines six creeds attributed to Ahmad ibn Hanbal and in the second Melchert responds with his assessment of Sarhan's examination, providing his own perspectives and counterviews apropos the creeds. A good sense of the significance of these creeds can be gauged from the study.

Daiber, Hans. "The Creed ('Aqīda) of the Ḥanbalite Ibn Qudāma al-Maqdisī." In Studia Arabica et Islamica, Festschrift for Insān 'Abbās on His Sixtieth Birthday. Edited by Wadād al-Qāọī, 105-125. Beirut, Lebanon: American University of Beirut, 1981.

Ibn Qudāma's reputation as an accomplished Hanbali jurist is renowned, yet he produced a number of tracts in defense of traditionist approaches to doctrine.

Gilliot, Claude. Exégese, langue, et théologie en Islam: l'exégese coranique de Tabarī (m. 311/923). Paris: J. Vrin, 1990. This is a comprehensive survey of al-Tabarī's thought and his position on key doctrinal points.

Halkin, A. S. "The Hashwiyya." Journal of the American Oriental Society 54 (1934): 1-28.

The origins of the label and its use as a pejorative term for anthropomorphists is explored in detail.

Holtzman, Livnat. “Accused of Anthropomorphism: Ibn Taymiyya's Mihan as Reflected in Ibn Qayyim al-Jawziyya's alKāfiya al-Shāfiya." The Muslim World 106.3 (2016): 561-587.

An attempt is made to explain Ibn Taymiyya's approach to the related issues through the work of his loyal student.

Hoover, Jon. "Ḥanbalī Theology." In The Oxford Handbook of Islamic Theology. Edited by Sabine Schmidtke, 625-646. New York: Oxford University Press, 2016.

This distinguishes nuances in the approach to the divine attributes and ta'wīl within Hanbali circles. It covers extended historical periods.

Hurvitz, Nimrod. The Formation of Hanbalism: Piety into Power. Richmond, UK: Curzon Press, 2002.

A survey of key developments in the history of Hanbali traditionalist thought is presented here, covering theological and legal discussions.

Laoust, Henri. La Profession de foi d'Ibn Batța. Damascus: Institut Français de Damas, 1958.

Ibn Bața is famed for his text entitled al-Ibāna which formulates the ahl al-hadîth (traditionist) approach to doctrine; the text has relevance to doctrinal teachings on tanzīh and tashbīh. 


\section{Shah, Mustafa. "Al-Ṭabarī and the Dynamics of tafsīr: Theological Dimensions of a Legacy." Journal of Qur'anic Studies} 15.2 (2013): 83-139.

This covers his exegetical approach to theological issues, reviewing tensions between traditionists and al-Tabarī on issues in which discussions about tanzīh and tashbīh dominate.

Swartz, Merlin. A Medieval Critique of Anthropomorphism: Ibn al-Jawzī’s Kitāb akhbār al-șifāt. Leiden, The Netherlands: E. J. Brill, 2002.

A critical edition of the Arabic text with translation, introduction, and notes, in English and Arabic. This text preserves important information about debates and disagreements concerning anthropomorphism from a medieval perspective and its author was a distinguished adherent of the Hanbali school.

Williams, Wesley. "Aspects of the Creed of Imam Ahmad ibn Hanbal: A Study of Anthropomorphism in Early Islamic Discourse." International Journal of Middle East Studies 34 (2002): 441-463.

Ibn Hanbal has traditionally been viewed as the archetypal representative of religious orthodoxy and his position on tanzīh and tashbì is explored here.

\section{Ash 'arīs}

The Ash 'arī contribution to the synthesis of rational Sunni discourses is definitive in the sense that their teachings on the divine attributes, tanzīh, and tashbīh hugely influenced the dynamics of classical theological debates. In Ramli 2016 a review is presented of the theological ideas developed by Ibn Kullāb (d. c. 241/855 CE), al-Qalānisī (fl. third/ninth centuries CE) and al-Muhāāsibī (d. 243/857 CE), including their teaching on the divine attributes. Allard 1965 provides an influential survey of the key features of the Ash 'arī teaching on the divine attributes. The thought of al-Ash arī (d. 324/925 CE) and materials germane to arguments about tanzīh and tashbīh are analyzed in several separate studies: Frank 1991 examines the characteristics of al-Ash 'arī's approach to the conceptual accentuation of the transcendence of God. He also refutes arguments presented in earlier studies by George Makdisi, offering critical observations on al-Ash 'arī's subtle use of bi-la kayf as a tool to defend the concept of God's transcendence. Further aspects of al-Ash 'arī's thought are assessed in detail in the study of his legacy in Gimaret 1990 . A key turning-point in Ash 'arī theological discourses in which issues of tanzīh loom large occurs in the Ghazālian era and two works which analyze different aspects of his position on points of theology are Frank 1994 and Griffel 2009. In the former al-Ghazāli's commitment to Ash arism is reviewed, while in Griffel the scale of his contribution to Islamic thought is assessed; Griffel differs with Frank about the nature of the paradigmatic framework within which al-Ghazālī (d. 555/1111) situated his cosmology. It should be noted that although these studies are not specifically devoted to tanzīh and tashbih they do explain the dynamics of his standpoint on these issues. Gimaret 1990 does broach the issues through overlapping theological and linguistic frameworks. The work of the theologian Fakhr al-Dīn al-Rāzī (d. 606/1210 CE) is hugely significant and Abrahamov detects in his work some key shifts in the parameters of discussions on the conceptualization of the divine attributes. These shifts impinge upon discussions about defining the doctrine of God's transcendence. The third volume of the collected articles of Frank 2008 focuses on Ash 'arī theology and a significant range of materials is brought together in the volume, including studies which examine the school's teaching on attributes and being as well as a tract on theological creeds by the medieval scholar Abū Isḥāq al-Isfarā'īnī (d. 418/1027 CE). Walker 2000 presents a translation of a primary Ash 'arī theological text by al-Juwaynī (d. 478/1085), who was al-Ghazālī's mentor and in this text the thrust of Ash 'arī teachings on tanzīh, tashbīh, and the divine attributes is included.

\section{Abrahamov, Binyamin. "Fakhr al-Dīn al-Rāzī on the Knowability of God's Essence and Attributes." Arabica 49.2 (2002): 204-230.}

Under the influence of philosophical trends, Abrahamov suggests that later theologians changed their views about whether the essence of God can ever be known by humans. 
Lebanon: Imprimerie Catholique, 1965.

This survey summarizes how key Ash 'arī theologians grappled with the issue of the divine attributes and the concept of God's transcendence.

Frank, Richard. “Elements in the Development of the Teaching of al-Ash 'arī." Le Museon: Revue D'Etudes Orientales, Tome 104 (1991): 141-190.

Frank provides a painstaking treatment of the factors behind al-Ash 'arīs approach to explaining the concept of the transcendence of God and his application of the bi-lā kayf formula; namely, the axiom of adopting a position of amodality as a means of defending the immutable nature of the divine attributes.

Frank, Richard. Al-Ghazālī and the Ash 'arite School. London: Duke University Press, 1994.

The principal argument in this text suggests that al-Ghazālì's Ash 'arī affiliations were tenuous, although his commitment to defending the importance of tanzīh remains undiminished.

Frank, Richard. Classical Islamic Theology: The Ash arites. Vol. 3, Texts and Studies on the Development and History of Kalām. Edited by Dimitri Gutas. Variorum Collected Studies Series. Burlington, VT, and Aldershot, UK: Ashgate, 2008.

It should be noted that Volume 2 of the collection includes materials on the Ash arīs, including two editions and translations of theological creeds by the mystic Abū'l-Qāsim al-Qushayrī (d. 465/1074).

Gimaret, Daniel. Les noms divins en Islam: exegese lexicographique et theologique. Paris: Cerf, 1988.

Although the book deals with broader theological and linguistic discussions about the divine attributes, it does offer detailed insights into the impact that arguments about transcendence had upon the general trajectories of debates within theological contexts.

Gimaret, Daniel. La doctrine d’al-Ash'arī. Paris: Cerf, 1990.

This offers a detailed synthesis of al-Ash 'arī's views, including those on tanzīh.

Griffel, Frank. Al-Ghazālī’s Philosophical Theology. Oxford: Oxford University Press, 2009.

This is a definitive study of al-Ghazālī's legacy which examines key theological positions within the schema of Ash 'arite thought.

Ramli, Harith. "The Predecessors of Ash arism: Ibn Kullāb, al-Muhāsibī and al-Qalānisī." In The Oxford Handbook of Islamic Theology. Edited by Sabine Schmidtke, 215-224. New York: Oxford University Press, 2016.

The origins of early Sunnī rational thought remain vague but the theological debates and discussions to which these individuals developed anticipated key aspects of later Ash 'arī scholarship; the subject is effectively broached in this chapter.

Walker, Paul. A Guide to Conclusive Proofs for the Principles of Belief. A Translation of al-Juwaynī's Kitāb al-Irshād ilā qawāți' al-adilla fi ușūl al-i tiqād. Reading, UK: Garnet, 2000.

This influential treatise includes sections on the khalq al-Qur'ān and the distinction between the heavenly Qur'anic prototype (kalām nafsì) and its earthly counterpart. And the section on the divine attributes shows the developed position of the school.

Mu'tazilīs 
The early history of speculative theological thought is dominated by the contribution made to its synthesis by Mu tazali theologians. They represented a school of theological thought within which reason was accentuated as the principal arbiter of truth in the conceptualization of doctrinal standpoints. The origin of the school is a subject of debate although not in dispute is the strength of the movement's ideas which positively influenced centuries of speculative theological discourses. Current scholars refer to the heterogeneity and diversity on doctrine within the developing school, although incontestable is the school's trenchant rejection of anthropomorphism as a hallmark of its doctrinal outlook. Besides, the fact that members of the school referred to themselves as the sentinels of tawhìd was an indication of their uncompromising stance on the issue of God's transcendence. They frequently referred to their ideological opponents among the traditionists as hashawiyya; and they too were pejoratively referred to as the $M u$ 'ațila (negators of the attributes) on account of their rejecting the substantive and hypostatic nature of the divine attributes. Gimaret 1987 analyzes the history of the school, presenting their teaching on God's unity and its impact upon approaches to tanzih and tashbïh. The detailed history and evaluation of key doctrinal standpoints are presented in Van Ess 1991-1997 and Van Ess 2011, which are indispensable references sources for the study of theological concepts. In the monograph by Wolfson 1976 Mu tazili theological constructs and concepts are reviewed in the context of perceived substrate Christian influences; the nexus with arguments about tanzīh and tashbīh is taken into account. Arguments about the epistemology of God's speech were informed by the Mu tazili position on transcendence and in Peters 1976 the theoretical dimensions of the debates are considered. The views on transcendence of an early Mu 'tazilī theologian, 'Abbād ibn Sulaymān (d. c. 250/864), are assessed in Abrahamov 1994. He actively took part in the debates of the mihna, engaging in disputations with Ibn Kullāb, the progenitor of Sunni rational speculative discourses. A translation of a text on Mu'tazilī creeds composed by al-Zamakhsharī is included in a study in Schmidtke 1997. Early Mu tazilī primary sources are rare but this French translation of al-Khayyāț's Kitāb al-Intișār, the book of defense, an apologia for their doctrines against the charges of Ibn al-Rawandī, a fourth/tenth century scholar, includes a wealth of "lost" sources, notably material on sects who were excoriated for their crude anthropomorphic positions. Frank 1978 offers a detailed analysis of the theoretical moorings of the arguments about attributes as referenced to tanzīh within the constructs of Mu tazili epistemology. In Adamson 2003 an attempt is made to trace the influence that Mu'tazili teachings on the divine attributes had upon the philosopher al-Kindī's teachings. An analysis of the theological thought of one of the most influential early Mu'tazili scholars is provided in Racha el-Omari 2016.

Abrahamov, Binyamin. “Abbād ibn Sulaymān on God's Transcendence. Some Notes.” Der Islam 71.1 (1994): $109-120$.

The theological roots of this figure's arguments are analyzed.

Adamson, Peter. "Al-Kindī and the Mu'tazila: Divine Attributes, Creation and Freedom." Arabic Sciences and Philosophy 13 (2003): 45-77.

Despite the fact that philosophers and theologians respectively adopted different epistemological frameworks, Adamson's study identifies similarities between the philosopher al-Kindī's conceptualization of the divine attributes and the position taken by the Mu'tazila.

Al-Khayyāṭ. "Abū'I-Ḥusayn ibn 'Uthmān.” In Kitāb al-Intișār. Edited and translated by Albert Nader. Beirut, Lebanon: Les Lettres Orientales, 1957.

This is an important primary Mu tazili source which includes statements on tashbīh attributed to various opponents and contemporaries.

El-Omari, Racha. The Theology of Abū I-Qāsim al-Balkhī/al-Ka 'bī (d. 319/931). Leiden, The Netherlands: E. J, Brill, 2016.

Al-Balkhī's teachings on the divine attributes are explored in an extended chapter.

Frank, Richard. Beings and Their Attributes: The Teaching of the Basrian School of the Mu tazila in the Classical Period. Albany: State University of New York Press, 1978.

The theoretical foundations of key Mu tazili doctrines are scrutinized with reference to a rich range of sources. This includes a detailed analysis of the theory of states developed by Abū Hāshim ibn al-Jubbā'ī. 
Gimaret, Daniel. "Entry on the 'Mu'tazila'." In the Encyclopaedia of Islam. 2d ed. Edited by P. Bearman, Th. Bianquis, C. E. Bosworth, E. van Donzel, and W. P. Heinrichs, 783-793. Leiden, The Netherlands: E. J. Brill, 1987.

This covers their history, doctrines, and impact on the evolution of rational theology. The movement's position on tanzin is summarized through reference to the principle of tawhid.

Martin, Richard, Mark R. Woodward, and Dwi S. Atmaja. Defenders of Reason: Mu tazilism from Medieval School to Modern Symbol. Oxford: Oneworld, 1997.

Although this work was aimed at showcasing the relevance of Mu tazilism to discourses in modern Islamic thought, it does include translated sections from the ușūl al-khamsa which are relevant to the debates about the divine attributes and the nature of God's speech.

Peters, J. R. God's Created Speech: A Study in the Speculative Theology of the Mu 'tazilī Qāọī al-Quọaāt Abū'l-Hasan 'Abd al-Jabbār ibn Ahmmad al-Hamadānī. Leiden, The Netherlands: E. J. Brill, 1976.

The work of 'Abd al-Jabbār has for years been a critical source for gauging early and classical Mu'tazilite thought and this study undertakes to unravel some of the complexities behind this figure's arguments for the uncreated nature of God's speech as outlined in the Kitāb al-Mughnī.

Schmidtke, Sabine. A Mu 'tazilite Creed of az-Zamakhsharī (d. 538/1144) (Al-Minhāj fi ușūl al-dīn). Edited and Translated. Stuttgart: Steiner, 1997.

Al-Zamakhsharī (d. 538/1144) was renowned for his skills as an exegete and linguist but in this text his synthesis of Mu'tazilī creeds shows the enduring impact of their theological ideas and concepts.

Van Ess, Josef. Theologie und Gesellschaft im 2. 3. jahrhundert Hidschra. Berlin: Walter de Gruyter, $1991-1997$.

Doctrinal nuances which relate to tanzīh and tashbih are covered in various chapters and sections of this work. It is an indispensable reference source for the academic study of Islamic theology.

Van Ess, Josef. Der Eine und das Andere. Beobachtungen an islamischen häresiographischen Texten. 2 vols. Berlin: de Gruyter, 2011.

In this survey of heresiographical texts and figures, the subjects of God's transcendence, anthropomorphism, and the divine attributes feature prominently.

Wolfson, Harry Austryn. The Philosophy of the Kalām. Cambridge, MA, London: Harvard University Press, 1976.

A chapter is devoted to exploring the origins of the Mu tazilite doctrine of the denial of the reality of the divine attributes. Wolfson posits that substrate Christian theological discussions influenced the genesis and evolution of concepts and ideas.

\section{Māturīdīs}

The school of theology associated with the legacy of Abū'l-Manșūr al-Maturīdī (d. 333/944 CE) played a pivotal role in the development of rational approaches to the defense of theological doctrines. Indeed, like its Ash 'arī complement, much of its theological thought is broadly fixated on the criticism and refutation of Mu'tazili doctrine and constructs, including the latter's conception of the divine attributes. Yet it too promoted an uncompromising critique of anthropomorphism. The authoritative study of the theology of al-Māturīdī was produced in Rudolph 1997. It explains the theoretical bases of his theology, discussing the influence and impact of his system of theological thought. Ceric 1995 covers the history and influence of the school. Madelung 2000 looks at 
the legacy of Abū'l-Mu 'īn al-Nasafī (d. 508/1114 CE), a scion within the later Māturīdī school. Aldosari 2013 is an edited critical edition of the work of a 13th-century adherent of the school, al-Khabbāzī, in which the more abstruse features of al-Māturīdī's teaching on God's transcendence is explained. Watt 1998 does include sections which present comparisons between Ash 'arī and Māturīdī theological doctrines. In Rudolph 2016, early stages of the interplay which defined the synthesis of Hanafi and Māturīdī theological thought are probed. Berger 2016 includes a review of theological views among later adherents of the two schools. Götz 1999 offers a detailed examination of al-Māturīdī's exegetical strategies and preserves disputes on points of exegesis as a corollary of literalist and rationalist approaches to theological constructs.

Aldosari, Ayed. A Critical Edition of al-Hādī in Māturīdī Doctrine of the Ḥanafite-Māturīdī Imām 'Umar al-Khabbāzī (d. 691/1292). PhD diss., Trinity Saint David University of Wales, 2013,

This is an unpublished $\mathrm{PhD}$ dissertation. Al-Khabbāzī was a theologian and jurist who brought conceptual resolution to the doctrines outlined by the eponym of the school and the original text includes discussions on the divine attributes.

Berger, Lutz. "Interpretations of Ash 'arism and Māturīdism in Mamluk and Ottoman Times." In The Oxford Handbook of Islamic Theology. Edited by S. Schmidtke, 693-703. Oxford: Oxford University Press, 2016.

This includes some discussion of the later schools' attitudes to the Hanbalis and issues specific to anthropomorphism.

Ceric, Mustafa. Roots of Synthetic Theology in Islam: A Study of the Theology of Abū Manșūr al-Māturīdī (d. 333/944). Kuala Lumpur: International Institute of Islamic Thought and Civilization, 1995.

This is a wide-ranging study of the principal characteristics of Māturīdī theology.

Götz, Manfred. “Māturīdī and His Kitāb Ta'wīlāt al-Qur'ān.” In Qur'ān: Formative Interpretation. Edited by Andrew Rippin, 181-214. Aldershot, UK: Variorum, 1999.

This is a translation of a 1965 study by Gotz in German and in it tensions on the issue of tanzih are explained in requisite detail.

Madelung, Wilferd. "Abū'l-Mu īn al-Nasafĩ and Ash arī Theology." In Studies in Honour of Clifford Edmund Bosworth. Vol. 2. The Sultan's Turret: Studies in Persian and Turkish culture. Edited by Carole Hillenbrand, 318-330. Leiden, The Netherlands: E. J. Brill, 2000.

Al-Nasafĩ was one of the key thinkers of the medieval periods within the school and produced some key commentaries on Māturīdī theological doctrine, including his seminal Tabșirat al-adilla, a theological summa.

Rudolph, Ulrich. Al-Māturīdī und die sunnitische Theologie in Samarkand. Leiden, The Netherlands: Brill, 1997.

An English translation of this text does exist: Al-Māturīdī and the Development of Sunnī Theology in Samarqand, translated by Rodrigo Adem (Leiden, The Netherlands: Biggleswade: Brill; 2013).

Rudolph, Ulrich. "Ḥanafi Theological Tradition and Māturīdism.” In The Oxford Handbook of Islamic Theology. Edited by S. Schmidtke, 280-296. Oxford: Oxford University Press, 2016.

The chapter also looks at later developments within the school.

Watt, Montgomery. The Formative Period of Islamic Thought. Oxford: Oneworld, 1998.

The historical development of the movement is discussed in the context of the other Sunni schools. First published 1973. 


\section{Shi is}

There has been a marked increase in the attention devoted to Shi i $i$ thought over recent decades and this has usefully brought into sharper focus the depth and range of their theological teachings and doctrines. Amir-Moezzi 2016 reviews the connection between rational and esoteric theology within early Shi i thought as well as explaining the movement's principles of religion. The well-known creed authored by Ibn Bābawayhi (d. 381/991-2 CE), which was translated in Fyzee 1942, represents the more traditional stream within Twelver Shi ism; interestingly, Ibn Bābawayhi was known to be averse to kalām based approaches to theology; medieval luminaries such as al-Shaykh al-Mufĩd (d. 413/1022 CE) and al-Sharīf al-Murtaḍā (d. 406/1016 CE) were more receptive to the discipline. Demonstrating this diversity, Mcdermott 1978 provides a comparative study of the theological doctrines and thought of alMufīd, in which Mu tazilī and Shi i ideas were adventurously fused and issues germane to tanzīh and tashbīh resonate within the study. The survey of Hälm 2004, which is a translation of his original work in German, aims to provide a broad treatment of the movement and its luminaries, but doctrinal controversies which relate to transcendence and anthropomorphism are alluded to within the book. The work of Kohlberg 1991 on Shi $i$ thought and doctrine spans several decades and some of his more influential studies are brought together in this volume. Individual topics of theological thought such as the divine attributes, which are critical to the articulation of the concept of tanzih , are examined in the monograph of Schmidtke 1991. The author focuses specifically on drawing attention to the influence that the Mu tazilī scholar Abu'l-Husayn al-Bașrī (d. 436/1044 CE), and even Fakhr al-Dīn al-Rāzī, had on the work and thought of al-Hillī (d. 726/1325 CE). Momen 1985 provides comparisons between Shi $i$ and Sunni perspectives on doctrinal matters. Although Daftary 2007 is devoted to analyzing the historical emergence of the Isma ilis, the early Shi $i$ groups are discussed in the introduction and some of their doctrinal positions on tashbih are explained. Haidar 2014 outlines the broader historical vista for understanding the genesis of the different Shi i movements and the views they shared. In Gleave 2007 an assessment is made of the extent to which the sayings of the imāms affected the synthesis of doctrine and this applies to issues of tawhid.

Amir-Moezzi, Mohammed. "Early Shi'i Theology." In The Oxford Handbook of Islamic Theology. Edited by Sabine Schmidtke. New York: Oxford University Press, 2016.

This reviews the concepts which shaped Shi i i theology, including its understanding of tawhid.

Daftary, Farhad. The Ismā īlīs: Their History and Doctrine. 2d ed. Cambridge, UK: Cambridge University Press, 2007.

This includes a chapter covering the early development of Shi i doctrine which explains the appearance of several renegade "extremist" groups (ghulāt) who identified with anthropomorphism.

Fyzee, A. A. A Shī īte Creed: A Translation of Risālatu'l-i tiqādāt of Muhammad b. 'Alī lbn Bābawayhi Al-Qummī, Known as Shaykh Sadūq. Oxford: Oxford University Press, 1942.

This work includes a plethora of traditions which are cited to back up doctrines.

Gleave, Robert. Scripturalist Islam: The History and Doctrines of the Akhbārī Shīī School. Leiden, The Netherlands: Brill, 2007.

This explores the manner by which the approach to Shi'i thought, including doctrine, was fleshed out within the Akhbārī movement.

Haidar, Najm. Shī'îlslam: An Introduction. Cambridge, UK: Cambridge University Press, 2014.

Although this work offers a general survey of all the branches of Shi 'ism, including the Isma 'ilis and the Zaydīs, it briefly touches on the movement's espousal of the Mu'tazili doctrine of tawhid and its repudiation of anthropomorphism. 
Hälm, Heinz. Shi ism. Edinburgh: Edinburgh University Press, 2004.

Historical junctures in the development of Shi $i$ thought are reviewed within this survey and it briefly deals with doctrinal differences and nuances.

Kohlberg, Etan. Belief and Law in Imamī Shī ism. Aldershot, UK: Variorum, 1991.

This is a collection of Kohlberg's various works. A number of the chapters tackle theological issues.

McDermott, Martin. The Theology of al-Shaykh al-Mufid. Beirut, Lebanon: Dar el-Machreq, 1978.

The book presents various creedal statements of al-Shaykh al-Mufīd, which betray the influences of the Baghdādī school of Mu tazilism, with the doctrinal theses and positions outlined by 'Abd al-Jabbār (d. 415/1025 CE). The issue of tanzīh is evident in the comparisons discussed.

Momen, Moojan. An Introduction to Shï ì Islam: The History and Doctrines of Twelver Shi ism. New Haven, CT: Yale University Press, 1985.

This provides a general survey of the evolution of their thought and practices.

Schmidtke, Sabine. The Theology of al- Allāma al-Ḥillī (d. 726/1325). Berlin: Klaus Schwarz, 1991.

Originally a thesis, this study traces theological influences in the work of al-Hilli and his synthesis of doctrine. It focuses particularly on the impact that Mu tazilī Abū'l-Husayn al-Bașrī (d. 436/1054 CE).

\section{Zaydīs}

Emerging as offshoot from Shi' ism, the Zaydī movement developed a subtle range of theological teachings on the divine attributes within which anthropomorphism was denounced. An historical overview of the movement is provided in Madelung 2002. Separately, Madelung 1965 offers a circumspect study of early Zaydī theological thought with reference to the work of Imam al-Qāsim. The connection between his theological thought and basic Mu'tazili doctrines is analyzed in Madelung 1989. Abrahamov 1996 reviews al-Qāsim's exegetical strategies when dealing with anthropomorphic materials in the Qur'an. A number of primary sources are translated in the brief survey by Abrahamov 1998. In Jarrar 2002 intersections on doctrinal issues between Imāmī and Zaydī doctrine are assessed. Ansari 2016 draws critical attention to the fact that certain Zaydī groups rejected Mu tazili doctrines while others were receptive to their teachings, including the doctrinal position on the divine attributes. The historical details of the group are covered in Hälm 2004. With a focus on the later historical periods of their thought and doctrines, Thiele 2010 examines the role played by Hassan al-Rașșās (d. 584/1188 CE) in the adoption of Mu tazili concepts and doctrines in Zaydism, highlighting shared ideological tenets such as tawhid. Finally, Ansari, et al. 2016 reviews the historical roots of Zaydī theological thought in Yemen.

\section{Abrahamov, Binyamin. Anthropomorphism and Interpretation of the Qur'ān in the Theology of al-Qāsim ibn Ibrāhīm —Kitāb al-Mustarshid. Leiden, The Netherlands: Brill, 1996.}

The introductory chapter offers an overview of some of the influential discussions on anthropomorphism within the early Islamic tradition from the perspective of a renowned Zaydī scholar.

Abrahamov, Binyamin. Islamic Theology: Traditionalism and Rationalism. Edinburgh: Edinburgh University Press, 1998.

This includes a number of early Zaydī theological texts. 
Ansari, Hassan. "The Shīī Reception of Mu tazilism (I): Zaydīs." In The Oxford Handbook of Islamic Theology. Edited by Sabine Schmidtke, 181-195. New York: Oxford University Press, 2016.

This chapter explores the significance of different theological trends as far as the reception of ideas is concerned within Zaydi theological thought.

Ansari, Hassan, Sabine Schmidtke, and Jan Thiele. "Zaydī Theology in Yemen." In The Oxford Handbook of Islamic Theology. Edited by Sabine Schmidtke, 473-493. New York: Oxford University Press, 2016.

Some sense of the background to Zaydī ideas is presented here and again it is the prominence of Mu 'tazilī influences which is striking in terms of the general thrust of the movement's teachings on tawhid.

Jarrar, Maher. "Some Aspects of Imāmī Influence on Early Zaydite Theology." In Islamstudien ohne Ende: Festschrift für Werner Ende zum 65 Geburtstag. Edited by Rainer Brunner, Monika Gronke, Jens Peter Laut, and Ulrich Rebstock, 201-223. Abhandlungen für die Kunde des Morgenlandes 54.1. Würzburg, Germany: Deutsche Morgenländische Gesellschaft, 2002.

This confirms the sophistication of the theological arguments developed by Zaydi scholars.

Hälm, Heinz. Shi ism. Edinburgh: Edinburgh University Press, 2004.

A brief section of the text introduces the Zaydīs.

Madelung, Wilferd. Der Imām al-Qāsim b. Ibrāhim und die Glaubenslehre der Zaiditen. Berlin: de Gruyter, 1965.

The theological legacy of Ibn al-Qāsim is explained in considerable detail.

Madelung, Wilferd. "Imām al-Qāsim ibn Ibrāhīm and Mu tazilism.” In On Both Sides of al-Mandab: Ethiopian, South-Arabic and Islamic Studies Presented to Oscar Löfgren on His Ninetieth Birthday 13 May 1988 by Colleagues and Friends. Edited by Ulla Ehrensvaerd and Christopher Toll, 39-48. Istanbul: Swedish research Institute, 1989.

Connections with Mu'tazilī theological teachings are probed, providing a broader sense of the import of al-Qāsim's position.

Madelung, Wilferd. "Zaydiyya." In Encyclopaedia of Islam. 2d ed. Vol. 11. Edited by P. J. Bearman, T. Bianquis, C. E. Bosworth, E. van Donzel, and W. P. Heinrichs, 477-481. Leiden, The Netherlands: Brill, 2002.

The entry explores not only the historical origins of the movement but also its distinctive theology.

Thiele, Jan. "Propagating Mu 'tazilism in the 6th/12th century Zaydiyya: al-Ḥasan al-Rasṣạ̄s." Arabica 57.5-6 (2010): 536-558.

Although not specifically concerned with issues pertaining to the divine attributes, this article reviews the reception of Mu tazili thought among Yemenī Zaydīs and therefore provides a useful historical context to Zaydī theology.

Isma ilis

Over the last few decades Isma 'ili thought and literature have become the focus of increased academic interest. The Isma'ili conception of God's utter transcendence, which lay beyond humans' grasp, was articulated with reference to Neoplatonic constructs and notions: conventional discourses of theology were deemed irrelevant within their thought, although as some of the 
studies listed below demonstrate their influence can be discerned with Isma ili thought and discussions. Daftary 2007 offers the most comprehensive historical study of movements and doctrines; his appreciation of the sources is unrivaled. He has also prepared a useful bibliography of relevant sources and materials, Daftary 2004. De Smet 2016 explains why for Isma'ili s kalām was considered such a futile endeavor and considers their doctrine of the sublime names. Madelung and Walker 1998 include much material which is relevant to anthropomorphism and transcendence as viewed from an Isma ili perspective. Elias 1995 draws attention to the confluence of theological and mystical ideals and their relevance and impact upon discourses on the divine attributes. The medieval conception of God's nature within Isma ili thought is characterized in Netton 1994 as "variations on a Neoplatonic theme" and a chapter is devoted to this subject in his study of the semiotics of Islamic philosophy and theology. Ebstein 2014 identifies Isma 'ili influences in the mystical thought of Ibn Masarra (d. 319/931 CE) and Ibn 'Arabī (d. 638/1240 CE) and this includes teachings on the divine names. Walker 1993 focuses on the work of Abu Ya qūb al-Sijistānī (d. c. 4th/10th CE) whose contribution to the synthesis of the tradition's teachings on the cosmology of the universe and the concept of an unknowable God were highly influential. In the collection of articles in Walker 2008 a range of his studies on Isma ili history and thought forms the basis of this volume. De Smet 2012 offers a critical survey of the philosophical bases of Isma ili thought. Finally, in Campanini 2008 a sketch of Islamic philosophical thought is mapped out and the key contributions to ideas on emanation and the nature of God with reference to Isma ili concepts are briefly explored.

Campanini, Massimo. An Introduction to Islamic Philosophy. Edinburgh: Edinburgh University Press, 2008.

The ideas of a number of influential Isma ili luminaries are covered in the survey.

Daftary, Farhad. Ismaili Literature: A Bibliography of Sources and Studies. London: I. B. Tauris, 2004.

Key works on theology are included in the survey.

Daftary, Farhad. The Ismā 'îlis: Their History and Doctrine. Rev. ed. 2d ed. Cambridge, UK: Cambridge University Press, 2007.

This extensive history places in detailed context the key doctrinal developments in the history of Isma ili thought, highlighting the connection with early forms of Shi' ism.

De Smet, D. La Philosophie Ismaelienne. Paris: Cerf, 2012.

This is a masterly survey of their doctrine and systems of thought.

De Smet, Daniel. "Ismā īīi Theology.” In The Oxford Handbook of Islamic Theology. Edited by Sabine Schmidtke, 313-324. New York: Oxford University Press, 2016.

This does show how kalām-based constructs were used by Isma'ili authors to develop a synthesis of the "attributes of the Intellect" despite their criticisms of theologians.

Ebstein, Michael. Mysticism and Philosophy in al-Andalus: Ibn Masarra, Ibn al- 'Arabì and the Ismā 'îlī Tradition. Leiden, The Netherlands: E. J. Brill, 2014.

As well as reviewing the bases of the Isma ili concept of God and creation, the book includes a study of the Hadith which mentions "Adam being created in his image." 
Elias, Jamal J. The Throne Carrier of God: The Life and Thought of 'Alā' ad-Dawla as Simnānī. Albany: State University of New York Press, 1995.

This provides a useful study of an influential Iranian Sufi, as outlining the thrust of his teachings has relevance for understanding links with Isma'ili ideas on cosmology.

Madelung, Wilferd, and Paul Walker. An Ismaili Heresiography, the bāb al-shayțān from Abū Tammām's Kitāb al-Shajara. Leiden, The Netherlands: E. J. Brill, 1998.

This book presents the doctrine and thought of seventy-two heretical sects of Islam as perceived from the perspective of an Isma ili heresiography.

Netton, lan. Allah Transcendent: Studies in the Structure and Semiotics of Islamic Philosophy, Theology and Cosmology. London: Curzon, 1994.

This covers a wide range of philosophical and theological systems of thought and arguments many of which intersect with the trajectories of discussions on the divine attributes and even emanation.

Walker, Paul. Early Philosophical Shiism: The Ismaili Neoplatonism of Abu Ya'qub al-Sijistani. Cambridge, UK: Cambridge University Press, 1993.

This includes a chapter on the theology of unqualified transcendence.

Walker, Paul. Fatimid History and Ismā 'īlī Doctrine. Aldershot, UK: Ashgate, 2008.

Some of the chapters cover key doctrines germane to approaches to the nature of God within Isma ili doctrine.

\section{Other Sunni Movements: Zāhirīs and Khārijīs}

The ahl al-hadīth and the sub-groups loyal to them such as ahl al-zāhir or literalists are generally presented as fostering an aversion to speculatively derived kalām-based strategies for the defense of faith. This is the case for the Zāhirites, whose ideological founder was Dāwūd ibn Khalaf al-Zāhirī (d. 270/884 CE), and his later followers. His ideas were given distinct definition in the works of the Andalusian scholar Ibn Hazm (d. 456/1064 CE). They adopted an approach to law which rejected analogical reasoning and the resort to personal opinion, promoting a strictly literalist interpretation of the law, although they strongly denounced tashbih. The monograph on the Zahirīs in Goldziher 1971 was originally published in 1884 and remains a useful source; it has recently been reissued. Aspects of the general views and the doctrinal positions which informed Ibn Hazm's thought can be consulted in Adang and Schmidtke 2013. Schmidtke 2013, focuses on his use of Mu tazili and Ash 'arī. Turki 2012 presents a wide-ranging survey of the school and includes a brief outline of their theological views which touch upon the condemnation of tashbih in the schema of Zāhirī thought. Although Arnaldez 1956 is chiefly concerned with the interplay of grammatical and theological ideas fostered within the scholarship of Ibn Hazm, he does provide some insights into his general standpoint with regards to tanzīh and tashbīh. Makin 1999 illustrates the extent to which conceptions of tanzīh were critical in Ibn Hazm's system of theological thought despite the school's adherence to literalism in its approach to law and the broaching of the subject of the 'Hand of God' illustrates that fact. The theological ideology of the Khārijīs enjoys an extended history. Although in classical doxographies it was often claimed that they shared views of tawhid with the Mu tazila in actual fact the nuances within their theological thought with regards to tanzīh, tashbih and the divine attributes reveal the distinctiveness of their theology. The principal theological doctrines of the lbādī movement, who were viewed as being moderate, are introduced and explained in Hoffman 2011. The decisive question of whether God would be physically witnessed in the hereafter is examined from the lbāọī perspective in Hoffman 2015b. Madelung 2016 investigates some of the unique features of early lbāọi teachings on the șifāt. While, Hoffman 2015a reviews traditional accounts of the historical emergence of the movement and summarizes its position on doctrinal issues. The study of lbāọi exegesis is the subject of the thesis of al-Shuaily 2001 and the relevance of the connection between doctrine and interpretation is examined. 
Adang, Camilla Maribel Fierro, and Sabine Schmidtke, eds. Ibn Hazm of Cordoba: The Life and Works of a Controversial Thinker. Leiden, The Netherlands: E. J. Brill, 2013.

Some sense of the huge scale of Ibn Hazm's contributions to intellectual thought and its Zāhirī context, including his theological thought, is presented in this volume.

al-Shuaily, Sulaiman. "Ibāọī Tafsīr: A Comparison Between the Tafsīrs of Hūd al-Huwwārī and Sa'īd al-Kindī." PhD diss., Edinburgh University, 2001.

These two exegetical texts were composed by key luminaries within the early tradition and preserve materials relevant to the doctrines espoused by the Ibāọīs. Unpublished thesis.

Arnaldez, R. Grammaire et théologie chez Ibn Hazm de Cordoue. Paris: J. Vrin, 1956.

The intersection between theology and grammar and how scholarship in one discipline impinged upon the genesis of ideas in the second is the subject of this seminal monograph by Arnaldez.

Goldziher, Ignaz. The Zahirites their Doctrine and Their History: A Contribution to the History of Islamic Theology. Translated by W. Benn. Leiden, The Netherlands: E. J. Brill, 1971.

Despite the fact that the text was written in the 19th century, it provides a valuable overview of the principles behind their theological thought and position on anthropomorphism.

Hoffman, Valerie. The Essentials of Ibāọī Islam. Syracuse, NY: Syracuse University Press, 2011.

There is a paucity of works which examine Khārijī theological thought and in this impressive study lbāḍi doctrines and teachings on tanzīh and tashbīh are evaluated.

Hoffman, Valerie. "Ibāọism: History, Doctrines, and Recent Scholarship." Religion Compass 9.9 (September $2015 a)$ : 297-307.

This article introduces not only a summary of the theological doctrines of the Ibāọīs, but also some of the developments regarding recent research of the movement.

Hoffman, Valerie. "Refuting the Vision of God in Ibāọi Theology." In Rereading Sources and Scholarly Works. Edited by Angeliki Ziaka, 245-253. Hildesheim, Germany Georg Olms Verlagsbuchhandlung, 2015b.

This chapter shows the sophistication of Ibāọī theological strategies.

Madelung, Wilferd. "Early Ibāọī Theology." In The Oxford Handbook of Islamic Theology. Edited by Sabine Schmidtke, 242-251. New York: Oxford University Press, 2016.

Discussed in this chapter is the school's teaching on the divine attributes.

Makin, Al. "The Influence of Zāhirī Theory on Ibn Hazm's Theology: The Case of His Interpretation of the Anthropomorphic Text 'The Hand of God'." Medieval Encounters 5.1 (1999): 112-120.

This explains the dynamic behind the theological positions taken by Zāăhirī scholars, drawing attention to the nexus between theology and law. 
Schmidtke, Sabine. "Ibn Hazm's Sources on Ash arism and Mu tazilism." In Ibn Hazm of Cordoba: The Life and Works of a Controversial Thinker. Edited by Camilla Adang, Maribel Fierro, and Sabine Schmidtke, 375-402. Leiden, The Netherlands: E. J. Brill, 2013.

This studies the distillation of sources used in the oeuvre of Ibn Hazm.

Turki, Abdel-Magid. "al-Z̄āhiriyya.” In Encyclopaedia of Islam. 2d ed. Edited by P. Bearman, Th. Bianquis, C. E. Bosworth, E. Van Donzel, W.P. Heinrichs. Leiden, The Netherlands: Brill, 2012

A brief historical survey of the movement is provided in this entry much of which is based on the work of the late Egyptian scholar Muhammad Abū Zahra.

\section{Sufism}

Within expressions of Islamic mysticism there exists such a broad and diverse range of perspectives and ideas intrinsically relevant to the debates about the divine attributes and conceptions of transcendence and anthropomorphism. These span from theosophical approaches to broaching the concept of the divine attributes to deliberations on hulūl (incarnation), pantheism, and even gnosis. Moreover, encountered in later articulations of Sufism was the influence of distinct philosophical elements. General surveys of Sufism will provide a good grounding in the historical genesis and design of many of these concepts and ideas and an accessible introduction to the subject is provided in Karamustafa 2007. In Nguyen 2016 it is the development of doctrines specific to Sufi thought and their characteristics which are investigated. Noting the existence of a seeming tension between certain aspects of Islamic theology and mysticism, Mayer 2008 examines how individual theological beliefs and doctrines were explained within a defined Sufi context. The seminal translation in Arberry 1977 presents a wide selection of traditional orthodox doctrines and the Sufi position on them as explicated by the mystic al-Kalābādhī. The Sufi orders and some of the controversial aspects of beliefs and practices are briefly considered in Trimingham 1971. Serving as a commentary on the Futūhāt al-Makkiyya, Chittick 1989 includes two sections in the work which deals with theology and ontology; while the author's introductory text in Murata and Chittick 1994 provides a very accessible analysis of key Sufi teachings on areas such as the divine attributes. Knysh 1999 includes a chapter which scrutinizes Ibn Taymiyya's critique of Ibn 'Arabī's views on pantheism and assesses accusations of Mu 'tazilī influences levelled at this figure. In a framework within which the concept of God's transcendence is critical, Shaikh 2012 assesses the potential of exploring issues of gender through Sufi discourses with specific reference to Ibn 'Arabī's thought. De Jong and Radtke 1999 serves as an essential reference text covering controversies across a broad historical and geographical setting. Nguyen 2012 analyzes at length how al-Qushayrī (d. 465/1072 CE) ingeniously reconciled Ash arī teachings on tanzīh, tashbīh, and the divine attributes with mystical constructs. Although Netton 1994 (cited under Surveys of Theological Thought: Tanzīh and tashbīh in Context) is primarily concerned with the place of God within Islamic and philosophical thought, it does include a chapter which covers the doctrine of ishrāq and wahda apropos concepts of transcendence as ruminated over in the works of al-Suhrawardi (d. 587/1191 CE) and Ibn 'Arabī. Aziz 2011 looks at the life of the mystic Ahmad lbn 'Alwān (d. 665/1266 CE), presenting his interesting synthesis of theological and mystical constructs and their place within the "orthodox" tradition.

\section{Arberry, A. J. The Doctrine of the Sufis: Kitāb al-Ta'arruf li-Madhhab ahl al-Tașawwuf. Cambridge, UK: Cambridge University Press, 1977.}

Translated from the Arabic of Abū Bakr al-Kalābādhī. This treatise shows just how effectively and creatively al-Kalābādhī was able to demonstrate the consistency of Sufi doctrines with the teachings of an established Sunni "orthodoxy," including positions on the divine attributes and the issue of the status of God's speech.

Aziz, Muhammad. Religion and Mysticism in Early Islam: Theology and Sufism in Yemen. London: I. B. Tauris, 2011.

A chapter in the book is devoted to his theological views and positions on a wide range of topics, including God's essence and transcendence. 
Chittick, William. Ibn 'Arabi’s Metaphysics of Imagination: The Sufi Path of Knowledge. Albany: State University of New York Press, 1989.

This serves as a guide to Ibn 'Arabī's seminal work titled the Meccan Revelations in which his teachings on theology are explored, especially the idea that the "real one" is incomparable and utterly transcendent.

De Jong, and B. Radtke. Islamic Mysticism Contested: Thirteen Centuries of Controversies and Polemics. Leiden, The Netherlands: E. J. Brill, 1999.

The volume comprises thirty-five articles in English, German, and French and covers a comprehensive range of issues, many of which relate to theological doctrine and beliefs.

Karamustafa, Ahmet. Sufism: The Formative Period. Edinburgh: Edinburgh University Press, 2007.

The book traces the historical development of Islamic mystical thought, outlining key movements and figures.

Knysh, Alexander. Ibn 'Arabì in the Later Tradition: The Making of a Polemical Image. Albany: State University of New York Press, 1999.

This book provides insights into the intricate disputes regarding the reception of Ibn 'Arabī's teachings within "orthodoxy," including defenses and critiques of his positions.

Mayer, Toby. "Theology and Sufism." In The Cambridge Companion to Classical Islamic Theology. Edited by Tim Winter, 258-285. Cambridge, UK: Cambridge University Press, 2008.

The chapter probes individual teachings championed by Sufi luminaries on subjects such as the divine attributes, bi-la kayf, transcendence, and attitudes to hulūl (incarnation).

Murata, S., and W. Chittick. The Vision of Islam. New York: Paragon House, 1994.

This introductory text explores a range of issues relevant to tanzīh and tashbīh within Sufi, theological and philosophical contexts.

Nguyen, Martin. Sufi Master and Qur'ān Scholar, Abū'l-Qāsim al-Qushayrī and the Lațā'if al-lshārāt. Oxford: Oxford University Press, 2012.

Included in the text is a chapter which focuses on al-Qushayrī's Ash 'arī allegiances and within this the topic of the divine attributes and anthropomorphism is salient.

Nguyen, Martin. "Sufi Theological Thought." In The Oxford Handbook of Islamic Theology. Edited by Sabine Schmidtke. New York: Oxford University Press, 2016.

This provides some context to how conventional theological doctrines on the divine attributes were articulated within the context of Sufi thought and beliefs. Included in this respect are discussions covering divine union, pantheism, and gnosis.

Shaikh, Sa'diyya. Sufi Narratives of Intimacy: Ibn 'Arabī, Gender, and Sexuality. Chapel Hill: University of North Carolina Press, 2012.

The text makes the broader point that at the heart of Ibn 'Arabī's metaphysics is an attempt to intertwine spiritual notions of God's transcendence with his immanence. 
Trimingham, Spencer J. The Sufi Orders in Islam. Oxford: Clarendon Press, 1971.

This work is, as indicated by the title, principally concerned with orders but does include a chapter which briefly covers ideologies.

\section{Philosophy}

The absolute transcendence of God and his immateriality were essential doctrines elaborated within Islamic philosophical thought. Within the related discussions, God is characterized by his unity and the reality that he is free from all attributes. Studies of the standpoints taken by key philosophers on the nature of God's transcendence feature in general historical surveys of Islamic philosophy and monographs devoted to the work of luminaries. Adamson 2016 offers an accessible introduction to different philosophical attempts to explain and defend the doctrine of God's transcendence and oneness; a much broader range of topics and luminaries is covered in Nasr and Leaman 1996. Adamson and Taylor 2005 provides a rich range of discussions on personalities and ideas. Janssens 1994 focuses exclusively on the theoretical framework of the conception of God as elaborated by one of the earliest Islamic philosophers, al-Kindī (d. 256/870 CE). He explains this with specific reference to the discussions in alKindî's On First Philosophy in which it is stressed that God is neither matter nor form; neither quantity nor number in the sense that God is utterly different from creation; and the belief that he is beyond the strictures of time. Switching to the work of al-Fārābi (d. 339/950 CE), a masterly survey of his thought and legacy is covered in Janos 2012 and this includes his use of the Neoplatonic theory of emanation. The Islamic tradition's most influential philosopher is Ibn Sīnā (d. 429/1037 CE) and avid interest in his work is reflected in the huge range of academic studies devoted to analyzing his legacy and thought. A concise introduction to Avicennan thought is provided in McGinnis 2010; and critical aspects of his theory of God as a necessary existent, which is considered one of his most influential concepts, are analyzed in Adamson 2013. Translations of key texts which cover his theories and thought are provided in Goichon (French) 1951, Inati (English) 1984, and Marmura (English). The influential study Leaman 1988 explores the legacy of the Andalusian scholar Ibn Rushd (d. 595/1198 CE), but crucially identifies the essential background to his teaching on the nature of God. It has been stated that the adoption of Ibn Sīnā's metaphysics played such a crucial role in the fleshing out and expression of the doctrines of philosophical mysticism. This is realized in the Islamic West in the works of luminaries such as Ibn 'Arabī, while in the Islamic East the efforts of thinkers such as al-Suhrawardī and Mullā Șadrā (d. 1050/1640 CE) marked key turning points in the synthesis of what was defined as illuminationist philosophy. Mulla Sadra's theological views on tanzīh, the nature of God, and the divine attributes are set out in his text entitled al-asfār al-arba'a. Two important assessments of his legacy are offered by Rizvi 2009 and Kalin 2014. Adamson, Peter. Interpreting Avicenna, 'From the Necessary Existent to God'. Edited by Peter Adamson, 170-189.
Cambridge, UK: Cambridge University Press, 2013.

This focuses on a discussion of the implications of Avicenna's concept of wājib al-wujūd and its relevance to the construct of God's uniqueness and simplicity which intricately relate to God's being uncaused.

Adamson, Peter. Philosophy in the Islamic World: A Very Short Introduction. Oxford: Oxford University Press, 2016.

Although the discussions are brief, the history of the nuances and distinctions introduced by philosophers to shore up conceptions of God's transcendence are explained with clarity.

\section{Adamson, Peter, and Richard C. Taylor. The Cambridge Companion to Arabic Philosophy. Cambridge, UK: Cambridge University Press, 2005.}

This is an essential reference work covering various themes and areas in philosophy within which issues germane to God's transcendence and nature are examined.

Ibn Sīnā. Kitāb al-īshārāt wa'l-tanbīhāt. Toronto, ON: Pontifical Institute of Mediaeval Studies, 1984.

Arabic edition by S. Dunya, Dar al-Ma ārif (Cairo, no date). French translation by A. M. Goichon, Livres des Directives et des Rémarques (Paris: Vrin, 1951). Parts of the text were translated by Shams Constantine Inati. Avicenna's key arguments on 
metaphysics are featured in the Kitāb al-īshārāt which is conventionally viewed as being his last work.

Kalin, Ibrahim. Mulla Sadra. Oxford: Oxford University Press, 2014.

This offers a detailed study of the thought of Mulla Sadra.

Janos, Damien. Method, Structure, and Development in al Fārābī's Cosmology. Leiden, The Netherlands: E. J. Brill, 2012. Although principally focused on providing an examination of the structural bases of al-Fārābī's philosophy, this work does shed light on the extent to which the Neoplatonic doctrine of the transcendence and ineffability of the One resonated in other aspects of his thought, including his teachings on the doctrine of the divine simplicity of God.

Janssens, Jules. "Al-Kindī's Concept of God.” Interdisciplinary Studies in the Philosophy of Understanding 17.1 (1994): 1-16.

The article brings together the main strands of al-Kindī's teachings on God's absolute transcendence.

Leaman, Oliver. Averroes and His Philosophy. Oxford: Clarendon Press, 1988.

Although renowned for his commentaries on Aristotle's work and his critique of al-Ghazālīs Tahāfut al-falāsifa, Ibn Rushd was particularly scathing of the Ash'arī concept of the divine attributes and this was tackled in a treatise titled Kashf 'an manāhij al-adilla $f i ́$ 'aqā'id al-milla. In his study of this figure's legacy Leaman sets the wider context for the elaboration of Ibn Rushd's philosophical thought.

Marmura, Michael E. The Metaphysics of The Healing: A Parallel English-Arabic Text = Al-Ilahīyāt min al-Shifā'. Provo, UT: Brigham Young University Press, 2005.

The work includes a chapter on the First Principle of all existence and knowledge of his attributes.

McGinnis, Jon. Avicenna. New York and Oxford: Oxford University Press, 2010.

The work has a chapter which examines Avicenna's Metaphysics and its theological foundations.

Nasr, Hossein, and Leaman, Oliver, eds. History of Islamic Philosophy. London and New York: Routledge, 1996.

Individual chapters in this volume cover key areas and figures in Islamic philosophy and issues of tanzīh and tashbīh frequently feature in the discussions.

Rizvi, Sajjad H. Mulla Sadra and Metaphysics: Modulation of Being. London: Routledge, 2009.

The theoretical foundations of Mulla Sadra's teachings on the divine attributes with reference to the asfär are analyzed; the text rehearses the impact that Akbarian monism had on Sadra's own synthesis of this concept.

back to top 
Tanzīh and Tashbīh in Classical Islamic Theological Thought - Islamic...

24 of 24 